\title{
Excess Molar Volumes and Refractive Indices of Tetrahydrofuran, Dichloromethane, Trichloromethane, 1, 2-Dichloroethane, Trichloroethane and 1, 1, 2, 2-Tetrachloroethane
}

\author{
C. P. Gupta ${ }^{1}$, Rajesh Singh ${ }^{2}$, Ram Janam Gupta ${ }^{3}$ \\ Chemistry Department, St. Andrew’s College Gorakhpur -273001(India)
}

\begin{abstract}
Excess molar volumes $\mathrm{V}_{\mathrm{m}}^{\mathrm{E}}$ at $T=303.15 \mathrm{k}$ and refractive indices $n$ at $T=298.15 \mathrm{~K}$ have been measured for binary liquid mixtures of tetrahydrofuran $\left(\mathrm{C}_{4} \mathrm{H}_{8} \mathrm{O}\right)$ with dichloromethane $\left(\mathrm{CH}_{2} \mathrm{Cl}_{2}\right)$, trichloromethane $\left(\mathrm{CHCl}_{3}\right)$, , 1,2- dichloroethane $\left(\mathrm{CH}_{2} \mathrm{ClCH} \mathrm{Cl}_{2}\right.$, trichloroethane $\left(\mathrm{CH}_{2} \mathrm{ClCHCl}_{2}\right)$ and 1,1,2,2-tetrachloroethane $\left(\mathrm{CHCl}_{2} \mathrm{CHCl}_{2}\right)$. The values of $\mathrm{V}_{\mathrm{m}}^{\mathrm{E}}$ have been found to be negative throughout the entire range of compositions for $\mathrm{XC}_{4} \mathrm{H}_{8} \mathrm{O}+(1-\mathrm{X}) \mathrm{CHCl}_{3}, \mathrm{XC}_{4} \mathrm{H}_{8} \mathrm{O}+(1-\mathrm{X}) \mathrm{CHClCCl}_{2}$, and $\mathrm{XC}_{4} \mathrm{H}_{8} \mathrm{O}+(1-\mathrm{X})$ $\mathrm{CHCl}_{2} \mathrm{CHCl}_{2}$. For $\mathrm{XC}_{4} \mathrm{H}_{8} \mathrm{O}+(1-\mathrm{X}) \mathrm{CH}_{2} \mathrm{Cl}_{2}$ the $\mathrm{V}_{\mathrm{m}}^{\mathrm{E}}$ have been found to be very slightly positive at very low values of molar fractions $\mathrm{X}$ of $\mathrm{C}_{4} \mathrm{H}_{8} \mathrm{O}$, and negative at the higher values of $X$ with inversion of sign of $\mathrm{V}_{\mathrm{m}}^{\mathrm{E}}$ occurring at $X=0.15 . F o r X C_{4} H_{8} O+(1-X)$ $\mathrm{CH}_{2} \mathrm{ClCH}_{2} \mathrm{Cl}$, the $\mathrm{V}_{\mathrm{m}}^{\mathrm{E}}$ has been found to be positive at lower values of $X$ and negative at higher values of $X$, with inversion of sign of $\mathrm{V}_{\mathrm{m}}^{\mathrm{E}}$ occurring at $X=0.7$. The values of $\mathrm{V}_{\mathrm{m}}^{\mathrm{E}}$ and $n$ have been fitted with the representative equations. The $\mathrm{V}_{\mathrm{m}}^{\mathrm{E}}$ has been discussed in the light of the existence of electron donor-acceptor interaction between the components.
\end{abstract}

Keywords: Excess molar volumes, Refractive indices, Mixture and tetrahydrofuran.

\section{Introduction}

This work continues the study programme devoted to mixture of n-donor component and chloroalkane, or chloroalkene. Such binary mixture is of considerable interest from the viewpoint of the existence of an electron donor-acceptor interaction between the components in the liquid state. In earlier work, Nath and Rashmi ${ }^{1,2}$ have measured excess molar volumes $\mathrm{V}_{\mathrm{m}}^{\mathrm{E}}$ speed of sound $(\mathrm{u})$ relative permittivities $\mathrm{E}_{\mathrm{r}}$ and viscosities (n) of binary liquid mixture of 1,4-dioxane $\left(\mathrm{C}_{4} \mathrm{H}_{8} \mathrm{O}_{2}\right)$ and dichloroethane $\left(\mathrm{CH}_{2} \mathrm{Cl}_{2}\right)$,or 1,2- dichloroethane $\left(\mathrm{CH}_{2} \mathrm{ClCH}_{2} \mathrm{Cl}\right)$ or trichloroethane $\left(\mathrm{CHClCCl}_{2}\right)$, or tetrachloroethane $\left(\mathrm{CCl}_{2} \mathrm{CCl}_{2}\right)$, or cyclohexane $\left(\mathrm{o}-\mathrm{C}_{6} \mathrm{H}_{12}\right)$ at various temperature. $\mathrm{Nath}^{3}$ has also measured the vapour pressures of this mixture. In addition Nath and Pandey ${ }^{4}$ have measured $\mathrm{V}_{\mathrm{m}}^{\mathrm{E}}$, and $\mathrm{Nath}^{5}$ has measured $\mathrm{u}$, for mixtures of $\mathrm{C}_{4} \mathrm{H}_{8} \mathrm{O}_{2}$ and 1,1,2,2- tetrachloroethane $\left(\mathrm{CHCl}_{2} \mathrm{CHCl}_{2}\right)$ at $\mathrm{T}=303.15 \mathrm{k}$. This work reports the measurements of $\mathrm{V}_{\mathrm{m}}^{\mathrm{E}}$ at $\mathrm{T}=303.15 \mathrm{~K}$, and of refractive indices $\mathrm{n}_{\mathrm{D}}$ at $\mathrm{T}=298.15 \mathrm{~K}$ for binary liquid mixture of tetrahydrpfuran $\left(\mathrm{C}_{4} \mathrm{H}_{8} \mathrm{O}\right)$ and $\mathrm{CH}_{2} \mathrm{Cl}_{2}$ or trichloromethane $\left(\mathrm{CHCl}_{3}\right)$ or $\mathrm{CH}_{2} \mathrm{ClCH}_{2} \mathrm{Cl}$ or $\mathrm{CHClCCl}_{2}$ or $\mathrm{CHCl}_{2} \mathrm{CHCl}_{2}$ and interprets the data obtained. Since organic liquid mixture are encountered in variety of areas and detailed studies about their mixing behavior is important from both practical and fundamental point of view, the results reported here in appear pertinent.

\section{Experimental}

HPLC grade chemicals dichloromethane and 1,2dichloroethane, both of stated minimum purity of $99.8 \%$ (GLC), uv spectral grade trichloroethane of stated minimum purity of $99.5 \%$ (GLC), AR grade 1,1,2,2tetrachloroethane of stated minimum purity of $99 \%$ (GLC) were all obtained from Sisco Research Laboratories, Mumbai, India. $\mathrm{CH}_{2} \mathrm{Cl}_{2}, \mathrm{CH}_{2} \mathrm{ClCH}_{2} \mathrm{Cl}_{2}$, and $\mathrm{CHClCHCl}$ were used without further purification. Liquid $\mathrm{CHCl}_{2} \mathrm{CHCl}_{2}$ was washed with $10 \%$ potassium carbonate solution, dried over anhydrous calcium chloride and then distilled fractionally. HPLC grade tetrahydrofuran of stated minimum purity of $99.8 \%$ (GLC) and HPLC grade trichloromethane of stated minimum purity of $99.5 \%$ ( GLC) were obtained from qualigens fine chemicals Mumbai, $\mathrm{C}_{4} \mathrm{H}_{8} \mathrm{O}_{2}$ was used without further purification. Liquid $\mathrm{CHCl}_{3}$ was shaken several times with distilled water to remove ethanol present as a stabilizer, dried over anhydrous calcium chloride, then distilled fractionally, and stored in dark colored bottle covered with black cloth.

The excess molar volumes $\mathrm{V}_{\mathrm{m}}^{\mathrm{E}}$ were measured with an uncertainty of the order of $\pm 0.002 \mathrm{~cm}^{3}$. Mol, ${ }^{-1}$ using a two- limbed pyrex glass dilatometer that was similar to that used by Nath et $\mathrm{al}^{6}$ amount of the two liquid components were confined separately over mercury in the absence of air spaces in the two limbs of the dilatometer, which was mounted on a stand and immersed in thermostat water bath, Temperature was controlled with 


\section{International Journal of Science and Research (IJSR) \\ ISSN (Online): 2319-7064 \\ Index Copernicus Value (2013): 6.14 | Impact Factor (2014): 5.m1}

an a constant of $\pm 0.001 \mathrm{~K}$. The mixture of the two liquids was achieved by rocking the cell back and forth through a definite angle, and the mercury levels in the capillary of the dilatometer were noted using a cathetometer with an accuracy of $\pm 0.001 \mathrm{~cm}$.

The refractive indices (sodium- D line) $\mathrm{n}_{\mathrm{D}}$ were measured with an accuracy of \pm 0.0002 units, using a thermostated Abbe ( Carl Zeiss) refractometer.

\section{Results and discussion}

The values of $\mathrm{V}_{\mathrm{m}}^{\mathrm{E}}$ for the present mixture of $\mathrm{C}_{4} \mathrm{H}_{8} \mathrm{O}$ and $\mathrm{CH}_{2} \mathrm{Cl}_{2}$ or $\mathrm{CHCl}_{3}$, or $\mathrm{CH}_{2} \mathrm{ClCH}_{2} \mathrm{Cl}$ or $\mathrm{CH}_{2} \mathrm{ClCHCl}_{2}$ or $\mathrm{CHCl}_{2} \mathrm{CHCl}_{2}$ at $\mathrm{T}=303.15 \mathrm{~K}$ are reported in table 1 , whereas the values of the refractive indices $\mathrm{n}_{\mathrm{D}}$ of these mixtures at $\mathrm{T}=298.15 \mathrm{~K}$ are reported in Table 2, where $\mathrm{X}$ refers to the mole fraction of $\mathrm{C}_{4} \mathrm{H}_{8} \mathrm{O}$ in the various mixture. $\mathrm{X}$ has an uncertainty of \pm 0.0001 . The present values of $\mathrm{n}_{\mathrm{D}}$ of $\mathrm{C}_{4} \mathrm{H}_{8} \mathrm{O}, \mathrm{CH}_{2} \mathrm{Cl}_{2}, \mathrm{CHCl}_{3}, \mathrm{CHClCHCl}_{2}$, $\mathrm{CHCl}_{2} \mathrm{CHCl}_{2}$, and $\mathrm{CHCl}_{2} \mathrm{CHCl}_{2}$ are 1.4050, 1.4212, $1.4428,1.4420,1.4250$ and 1.4916 respectively at $\mathrm{T}=$ $298.15 \mathrm{~K}$, as compared with the corresponding values $1.40496,1.42115,1.44293,1.4421,1.4748$ and 1.49168 at $\mathrm{T}=298.15 \mathrm{~K}$ respectively for the various liquids in the same order, as reported by Riddick and Banger ${ }^{8}$, and Timmermans ${ }^{9}$ The experimental values of $\mathrm{V}_{\mathrm{m}}^{\mathrm{E}}$ for the various systems of $\mathrm{C}_{4} \mathrm{H}_{8} \mathrm{O}$ have been plotted against the mole fraction $\mathrm{x}$ of $\mathrm{C}_{4} \mathrm{H}_{8} \mathrm{O}$ in Fig. 1, and have been fitted by the method of least squares with a Radlich - Kister ${ }^{10}$ type equation.

$$
\mathrm{V}=\mathrm{x}(1-\mathrm{x}) \sum \mathrm{A}_{\mathrm{J}}(2 \mathrm{x}-1)^{\mathrm{J}-1}
$$

The values of the coefficients $\mathrm{A}_{\mathrm{J}}$ of Eq. 1 along with the standard deviations $\mathrm{V}_{\mathrm{m}}^{\mathrm{E}}$ for the various systems are given in Table 3.

The values of the refractive indices $n_{D}$ for the various systems have been fitted by the method of least squares with the equation

$$
\mathrm{n}_{\mathrm{D}}=\sum \mathrm{B}_{\mathrm{J}} \mathrm{X}
$$

The values of the coefficients $B_{J}$ of Eq. (2), along with the standard deviations $\left(\mathrm{n}_{\mathrm{D}}\right)$ are given in Table 4.

The present data show that the values of $\mathrm{V}_{\mathrm{m}}^{\mathrm{E}}$ at $\mathrm{T}=303.15 \mathrm{~K}$ are negative throughout the entire range of composition for $\mathrm{X} \mathrm{C}_{4} \mathrm{H}_{8} \mathrm{O}+(1-\mathrm{X}) \mathrm{CHCl}_{3}, \mathrm{X} \mathrm{C}_{4} \mathrm{H}_{8} \mathrm{O}+(1-\mathrm{X})$ $\mathrm{CHClCCl}_{2}$ and $\mathrm{X} \mathrm{C}_{4} \mathrm{H}_{8} \mathrm{O}+(1-\mathrm{X}) \mathrm{CHCl}_{2} \mathrm{CHCl}_{2}$. For $\mathrm{xC}_{4} \mathrm{H}_{8} \mathrm{O}+(1-\mathrm{X}) \mathrm{CH}_{2} \mathrm{Cl}_{2}$ the $\mathrm{V}_{\mathrm{m}}^{\mathrm{E}}$ is found to be very slightly positive a low values of $\mathrm{X}$, and negative at high $\mathrm{X}$ values with inversion of sign of $\mathrm{V}_{\mathrm{m}}^{\mathrm{E}}$ from positive to negative values occurring at $\mathrm{X} \approx 0.15$. Also for $\mathrm{XC}_{4} \mathrm{H}_{8} \mathrm{O}$ $+(1-\mathrm{X}) \mathrm{CH}_{2} \mathrm{ClCHCl}$, the $\mathrm{V}_{\mathrm{m}}^{\mathrm{E}}$ is found to be positive at lower values of $\mathrm{X}$, and very slightly negative at high values of $\mathrm{X}$, with inversion of sign from positive to negative values occurring at $V_{m}^{E} X \approx 0.7$. At $X=0.5$, the values of $\mathrm{V}$ system of $\mathrm{C}_{4} \mathrm{H}_{8} \mathrm{O}$ have the following various present sequences:

$\underset{\mathrm{CHCl}_{2} \mathrm{CHCl}_{2}}{\mathrm{CH}_{2} \mathrm{ClCH}_{2} \mathrm{Cl}}>\mathrm{CH}_{2} \mathrm{Cl}_{2}>\mathrm{CHClCCl}_{2}>\mathrm{CHCl}_{3}>$

The values of $\mathrm{V}_{\mathrm{m}}^{\mathrm{E}}$ may be interpreted in terms of the strength of intermolecular interaction between the molecules of the compositions of a given system. The negative values of $\mathrm{V}_{\mathrm{m}}^{\mathrm{E}}$ for a given system are attributed to a closer approach of unlike molecules of a system, leading to reduction in volume of mixture. The different types of forces that can exist between the molecules of the components of given systems are dispersion forces and charge transfer, hydrogen bonding, dipole - dipole, and dipole- induced dipole interaction. Dispersion forces leads to attraction between the molecules, and the relative magnitudes of the 1-1,2-2,1-2 type interactions between the molecules of components 1 and 2of a mixture are important in determining the thermodynamic excess properties. If the components of a mixture do not differ greatly in shape and size, the dispersion forces should make positive contributions to $\mathrm{V}_{\mathrm{m}}^{\mathrm{E}}$. However, the chargetransfer, hydrogen bonding, dipole- dipole and dipoleinduced dipole interactions shEuld normally lead to negative contributions to $\mathrm{V}_{\mathrm{m}}^{\mathrm{E}}$. Dispersion forces exist between the components of all systems, and for a given system in which there is more than one type of interactions between the molecules of the components, the values of $\mathrm{V}$ would be due to the net result of the contributions of all types of interactions. The highly negative values of $\mathrm{V}_{\mathrm{m}}^{\mathrm{E}}$ for $\mathrm{X} \mathrm{C}_{4} \mathrm{H}_{8} \mathrm{O}+(1-\mathrm{X}) \mathrm{CHCl}_{3}, \mathrm{X}$ $\mathrm{C}_{4} \mathrm{H}_{8} \mathrm{O}+(1-\mathrm{X}) \quad \mathrm{CHClCCl}_{2}$ and $\mathrm{X} \quad \mathrm{C}_{4} \mathrm{H}_{8} \mathrm{O} \quad+(1-\mathrm{X})$ $\mathrm{CHCl}_{2} \mathrm{CHCl}_{2}$ show that $\mathrm{C}_{4} \mathrm{H}_{8} \mathrm{O}$ forms strong intermolecular complexes with $\mathrm{CHCl}_{3}, \mathrm{CHClCCl}_{2}$, and $\mathrm{CHCl}_{2} \mathrm{CHCl}_{2}$ in the liquid state. The specific interaction leading to the formation of complexes of $\mathrm{C}_{4} \mathrm{H}_{8} \mathrm{O}$ with $\mathrm{CHCCl}_{3}, \mathrm{CHClCCl}_{2}$, and $\mathrm{CHCl}_{2} \mathrm{CHCl}_{2}$ in the liquid state may be visuflized as being due to the formation of hydrogen bonding between the components on account of interaction of $\mathrm{H}$ atoms in $\mathrm{CHCl}_{3}, \mathrm{CHClCCl}_{2}$ and $\mathrm{CHCl}_{2} \mathrm{CHCl}_{2}$ with the lone -pair electrons on the oxygen atom of $\mathrm{C}_{4} \mathrm{H}_{8} \mathrm{O}$, as it is know ${ }^{11,12}$ that 1,4- dioxane $\left(\mathrm{C}_{4} \mathrm{H}_{8} \mathrm{O}_{2}\right)$ forms the complexes $\mathrm{C}_{4} \mathrm{H}_{8} \mathrm{O}_{2} . \mathrm{CHCCl}_{3}$ and $\mathrm{C}_{4} \mathrm{H}_{8} \mathrm{O}_{2}$. ${ }_{2} \mathrm{CHCCl}_{3}$ with $\mathrm{CHCCl}_{3}$ via the interaction of $\mathrm{H}$ atom of $\mathrm{CHCCl}_{3}$ with lone - pair electrons on the oxygen atoms of $\mathrm{C}_{4} \mathrm{H}_{8} \mathrm{O}_{2}$. There is all likelihood of the formation of the strong hydrogen bonding between the molecules of $\mathrm{C}_{4} \mathrm{H}_{8} \mathrm{O}$ and $\mathrm{CH}_{2} \mathrm{Cl}_{2}$, or $\mathrm{CH}_{2} \mathrm{ClCH}_{2} \mathrm{Cl}$. The values of $\mathrm{V}_{\mathrm{m}}^{\mathrm{E}}$ which are slightly positive at low $\mathrm{x}$ values and slightly negative at high $\mathrm{X}$ values, do not support the viewpoint of the existence of the formation of strong complexes of $\mathrm{C}_{4} \mathrm{H}_{8} \mathrm{O}$ with $\mathrm{CH}_{2} \mathrm{Cl}_{2}$ and $\mathrm{CH}_{2} \mathrm{ClCHCl}$ in the liquid state . This may be thought of being due to the predominance of the contributions to $\mathrm{V}_{\mathrm{m}}^{\mathrm{E}}$ arising from non - specific interactions over those from specific interactions between the components of the systems $\mathrm{X} \mathrm{C}_{4} \mathrm{H}_{8} \mathrm{O}+(1-\mathrm{X}) \mathrm{CH}_{2} \mathrm{Cl}_{2}$ and $\mathrm{X} \mathrm{C}_{4} \mathrm{H}_{8} \mathrm{O}+(1-\mathrm{X}) \mathrm{CH}_{2} \mathrm{ClCH}_{2} \mathrm{Cl}$

\section{Volume 4 Issue 12, December 2015}




\section{International Journal of Science and Research (IJSR) \\ ISSN (Online): 2319-7064}

Index Copernicus Value (2013): 6.14 | Impact Factor (2014): 5.611

\section{List of Symbols}

$\mathrm{A}_{\mathrm{J}==}$ Coefficients of Redlich - Kister type equation fitting the values of $\mathrm{V}$

$\mathrm{AR}==$ Analytical reagent

$B_{J=}=$ Coefficients of the equation fitting the values of $n_{D}$

$\epsilon_{\mathrm{r}}==$ Relative permittivity

$\mathrm{GLC}==$ Gas liquid chromatography

HPLC $==$ High performance liquid chromatography

$\mathrm{n}$-donor $==$ Lone - pair electron donor

$\mathrm{n}_{\mathrm{D}==}$ Refractive index for sodium $-\mathrm{D}$ light

$\delta\left(\mathrm{n}_{\mathrm{D}}\right)==$ Standard deviation in $\mathrm{n}_{\mathrm{D}}$

$\eta==$ Dynamic viscosity

$\mathrm{T}==$ Temperature

$\mathrm{U}==$ Speed of sound

Table: 1 Experimental values of the excess molar volumes, $\mathrm{V}_{\mathrm{m}}^{\mathrm{E}}$, For $\mathrm{C}_{4} \mathrm{H}_{8} \mathrm{O}+\mathrm{CH}_{2} \mathrm{Cl}_{2}$, or $\mathrm{CHCl}_{3}$, or $\mathrm{CH}_{2} \mathrm{ClCH}_{2} \mathrm{Cl}$, or $\mathrm{CHClCCl}_{2}$, or $\mathrm{CHCl}_{2} \mathrm{CHCl}_{2}$ at $\mathrm{T}=303.15 \mathrm{k}$
$\mathrm{UV}==$ Ultraviolet

$\mathrm{V}_{\mathrm{m}}^{\mathrm{E}}==$ Excess molar volume

$\delta\left(\mathrm{V}_{\mathrm{m}}^{\mathrm{E}}\right)==$ Standard deviation in $\mathrm{V}_{\mathrm{m}}^{\mathrm{E}}$

\section{Acknowledgements}

The authors are thankful to the Head of the Chemistry Department, DDU Gorakhpur University, Gorakhpur and Principal of St. Andrew's College Gorakhpur, for providing laboratory facilities. Thanks are also due to the University Grants Commission, New Delhi, India, for financial support.

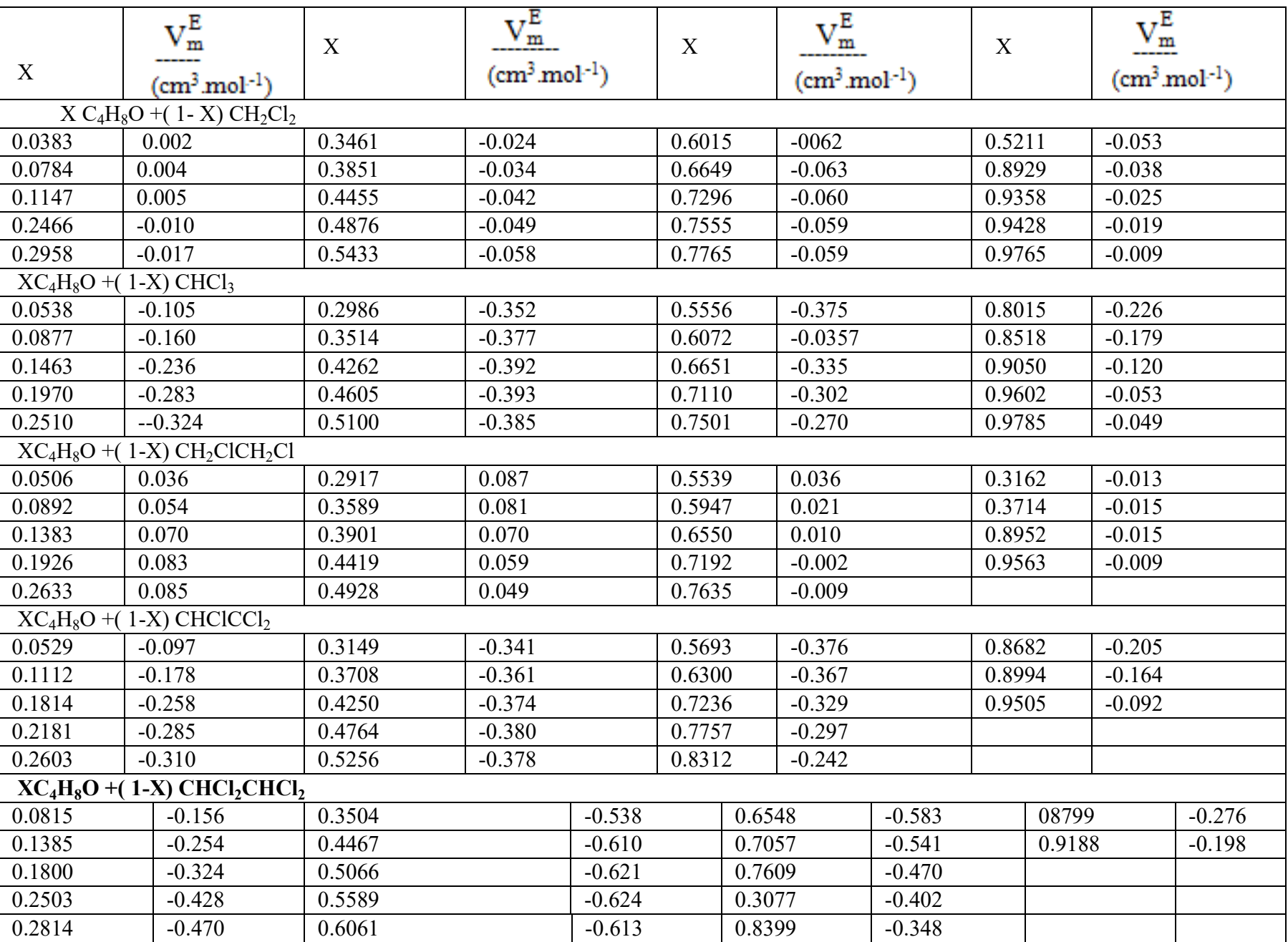




\section{International Journal of Science and Research (IJSR) \\ ISSN (Online): 2319-7064 \\ Index Copernicus Value (2013): 6.14 | Impact Factor (2014): 5.611}

Table: 2 Experimental values of the refractive indices, $\mathrm{n}_{\mathrm{D}}$ of $\left(\mathrm{C}_{4} \mathrm{H}_{8} \mathrm{O}+\mathrm{CH}_{2} \mathrm{Cl}_{2}, \mathrm{CHCl}_{3}, \mathrm{CH}_{2} \mathrm{ClCH}_{2} \mathrm{Cl}_{,} \mathrm{CHClCCl}_{2}\right.$ $\left.\mathrm{CHCl}_{2} \mathrm{CHCl}_{2}\right)$ at $\mathrm{T}=298.15 \mathrm{~K}$

\begin{tabular}{|c|c|c|c|c|c|c|c|}
\hline$X$ & $\mathrm{n}_{\mathrm{D}}$ & $X$ & $\mathrm{n}_{\mathrm{D}}$ & $X$ & $\mathrm{n}_{\mathrm{D}}$ & $X$ & $\mathrm{n}_{\mathrm{D}}$ \\
\hline \multicolumn{8}{|c|}{$\mathrm{XC}_{4} \mathrm{H}_{8} \mathrm{O}+(1-\mathrm{X}) \mathrm{CH}_{2} \mathrm{Cl}_{2}$} \\
\hline 0.0856 & 1.4198 & 0.2934 & 1.4166 & 0.5330 & 1.4125 & 0.8044 & 1.4083 \\
\hline 0.1188 & 1.4190 & 0.3479 & 1.4155 & 0.5855 & 1.4118 & 0.8523 & 1.4073 \\
\hline 0.1707 & 1.4183 & 0.3883 & 1.4148 & 0.6357 & 1.4109 & & \\
\hline 0.2156 & 1.4176 & 0.4384 & 1.4140 & 0.6866 & 1.4100 & & \\
\hline 0.2527 & 1.4171 & 0.4835 & 1.4132 & 0.7449 & 1.4090 & & \\
\hline \multicolumn{8}{|c|}{$\mathrm{XC}_{4} \mathrm{H}_{8} \mathrm{O}+(1-\mathrm{X}) \mathrm{CHCl}_{3}$} \\
\hline 0.1089 & 1.4392 & 0.3008 & 1.4325 & 0.5020 & 1.4252 & 0.7381 & 1.4153 \\
\hline 0.1509 & 1.4379 & 0.3604 & 1.4304 & 0.5450 & 1.4237 & 0.7961 & 1.4130 \\
\hline 0.2041 & 1.4360 & 0.3981 & 1.4289 & 0.6455 & 1.4192 & & \\
\hline 0.2550 & 1.4342 & 0.4473 & 1.4273 & 0.6929 & 1.4173 & & \\
\hline \multicolumn{8}{|c|}{$\mathrm{XC}_{4} \mathrm{H}_{8} \mathrm{O}+(1-\mathrm{X}) \mathrm{CH}_{2} \mathrm{ClCH}_{2} \mathrm{Cl}$} \\
\hline 0.1091 & 1.4393 & 0.3370 & 1.4330 & 0.6008 & 1.4240 & 0.8834 & 1.4118 \\
\hline 0.1405 & 1.4386 & 0.3873 & 1.4314 & 0.6355 & 1.4227 & & \\
\hline 0.2401 & 1.4360 & 0.4275 & 1.4300 & 0.6796 & 1.4208 & & \\
\hline 0.2905 & 1.4344 & 0.4898 & 1.4279 & 0.7909 & 1.4162 & & \\
\hline \multicolumn{8}{|c|}{$\mathrm{XC}_{4} \mathrm{H}_{8} \mathrm{O}+(1-\mathrm{X}) \mathrm{CHClCCl}_{2}$} \\
\hline 0.1146 & 1.4689 & 0.3363 & 1.4570 & 0.5704 & 1.4408 & 0.8036 & 1.4222 \\
\hline 0.1664 & 1.4664 & 0.3691 & 1.4546 & 0.6660 & 1.4336 & 0.8469 & 1.4134 \\
\hline 0.2224 & 1.4634 & 0.4177 & 1.4514 & 0.7137 & 1.4298 & & \\
\hline 0.2686 & 1.4608 & 0.4724 & 1.4478 & 0.7576 & 1.4260 & & \\
\hline \multicolumn{8}{|c|}{$\mathrm{XC}_{4} \mathrm{H}_{8} \mathrm{O}+(1-\mathrm{X}) \mathrm{CHCl}_{2} \mathrm{CHCl}_{2}$} \\
\hline 0.0762 & 1.4875 & 0.3455 & 1.4702 & 0.6517 & 1.4445 & 0.9067 & 1.4166 \\
\hline 0.1338 & 1.4844 & 0.4582 & 1.4618 & 0.6829 & 1.4415 & 0.9525 & 1.4112 \\
\hline 0.2293 & 1.4784 & 0.5079 & 1.4576 & 0.7536 & 1.4340 & & \\
\hline 0.2444 & 1.4774 & 0.5440 & 1.4544 & 0.8257 & 1.4260 & & \\
\hline 0.3057 & 1.4734 & 0.6073 & 1.4486 & 0.8535 & 1.4228 & & \\
\hline
\end{tabular}

Table: 3 Values of the coefficients A j of equation-1 and the standard deviations $\delta\left(\mathrm{V}_{\mathrm{m}}^{\mathrm{E}}\right)$ for $\left(\mathrm{C}_{4} \mathrm{H}_{8} \mathrm{O}+\mathrm{CH}_{2} \mathrm{Cl}_{2}, \mathrm{CHCl}_{3}\right.$ $\left.\mathrm{CH}_{2} \mathrm{ClCH}_{2} \mathrm{Cl}, \mathrm{CHClCCl}_{2}, \mathrm{CHCl}_{2} \mathrm{CHCl}_{2}\right)$ at $\mathrm{T}=303.15 \mathrm{~K}$

\begin{tabular}{|l|l|l|l|l|l|}
\hline System & \multicolumn{1}{|c|}{$\frac{\mathbf{A}_{\mathbf{l}}}{\left(\mathbf{c m}^{\mathbf{3}} \cdot \mathbf{m} \mathbf{m l}^{-\mathbf{1}}\right)}$} & $\frac{\mathbf{A}_{\mathbf{2}}}{\left(\mathbf{c m}^{\mathbf{3}} \cdot \mathbf{m} \mathbf{o l}^{-\mathbf{1}}\right)}$ & $\frac{\mathbf{A}_{\mathbf{3}}}{\left(\mathbf{c m}^{\mathbf{3}} \cdot \mathbf{m o l}^{-\mathbf{1}}\right)}$ & $\frac{\mathbf{A}_{4}}{\left(\mathbf{c m}^{\mathbf{3}} \cdot \mathbf{m o l}^{-\mathbf{1}}\right)}$ & $\frac{\mathbf{A}_{\mathbf{5}}}{\left(\mathbf{c m}^{\mathbf{3}} \cdot \mathbf{m o l}^{-\mathbf{1}}\right)}$ \\
\hline $\mathrm{XC}_{4} \mathrm{H}_{8} \mathrm{O}+(1-\mathrm{X}) \mathrm{CH}_{2} \mathrm{Cl}_{2}$ & -0.19860 & -0.27289 & 0.02878 & 0.00421 & 0.0016 \\
\hline $\mathrm{XC}_{4} \mathrm{H}_{8} \mathrm{O}+(1-\mathrm{X}) \mathrm{CHCl}_{3}$ & -1.54754 & -0.24433 & -0.21234 & 0.16915 & 0.0028 \\
\hline $\mathrm{XC}_{4} \mathrm{H}_{8} \mathrm{O}+(1-\mathrm{X}) \mathrm{CH}_{2} \mathrm{ClCH}_{2} \mathrm{Cl}$ & -0.18860 & -0.48260 & 0.09279 & -0.04958 & 0.0018 \\
\hline $\mathrm{XC}_{4} \mathrm{H}_{8} \mathrm{O}+(1-\mathrm{X}) \mathrm{CHClCCl}_{2}$ & -1.52172 & -0.03423 & -0.50145 & 0.04858 & 0.0024 \\
\hline $\mathrm{XC}_{4} \mathrm{H}_{8} \mathrm{O}+(1-\mathrm{X}) \mathrm{CHCl}_{2} \mathrm{CHCl}_{2}$ & -2.49710 & -0.33292 & 0.24320 & 0.04505 & 0.0025 \\
\hline
\end{tabular}

Table 4: Values of the coefficients $\mathrm{B}_{\mathrm{j}}$ of equation- 2 and the stander deviation $\delta \mathrm{n}_{\mathrm{D}}$ for $\mathrm{C}_{4} \mathrm{H}_{8} \mathrm{O}+\mathrm{CH}_{2} \mathrm{Cl}_{2}$, or $\mathrm{CHCl}_{3}$ or $\mathrm{CH}_{2} \mathrm{ClCH}_{2} \mathrm{Cl}$ or $\mathrm{CHClCCl}_{2}$ or $\mathrm{CHCl}_{2} \mathrm{CHCl}_{2}$ at $\mathrm{T}=298.15 \mathrm{~K}$

\begin{tabular}{|l|c|c|c|c|}
\hline \multicolumn{1}{|c|}{ Systems } & $\mathbf{B}_{\mathbf{1}}$ & $\mathbf{B}_{\mathbf{2}}$ & $\mathbf{B}_{\mathbf{3}}$ & $\boldsymbol{\delta} \mathbf{n}_{\mathbf{D}}$ \\
\hline $\mathrm{XC}_{4} \mathrm{H}_{8} \mathrm{O}+(1-\mathrm{X}) \mathrm{CH}_{2} \mathrm{Cl}_{2}$ & 1.421126 & -0.016191 & -0.000067 & 0.00011 \\
\hline $\mathrm{XC}_{4} \mathrm{H}_{8} \mathrm{O}+(1-\mathrm{X}) \mathrm{CHCl}_{3}$ & 1.442947 & -0.033139 & -0.005171 & 0.00023 \\
\hline $\mathrm{XC}_{4} \mathrm{H}_{8} \mathrm{O}+(1-\mathrm{X}) \mathrm{CH}_{2} \mathrm{ClCH}_{2} \mathrm{Cl}$ & 1.441722 & -0.019958 & -0.016198 & 0.00027 \\
\hline $\mathrm{XC}_{4} \mathrm{H}_{8} \mathrm{O}+(1-\mathrm{X}) \mathrm{CHClCCl}_{2}$ & 1.474834 & -0.045979 & -0.024085 & 0.00019 \\
\hline $\mathrm{XC}_{4} \mathrm{H}_{8} \mathrm{O}+(1-\mathrm{X}) \mathrm{CHCl}_{2} \mathrm{CHCl}_{2}$ & 1.491263 & -0.046070 & -0.039937 & 0.00019 \\
\hline
\end{tabular}

Volume 4 Issue 12, December 2015 


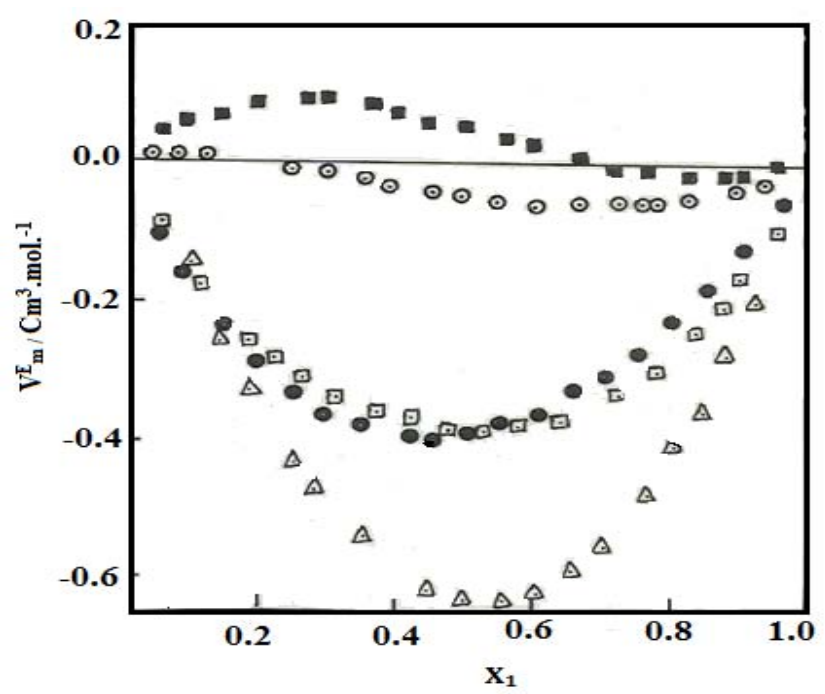

Fig. 1. Plot of Excess Molar Volume, $\mathrm{Vm}^{\mathrm{E}}$, against the mole

fraction of $\mathrm{C}_{4} \mathrm{H}_{8} \mathrm{O}, X$, for the following systems at $T=303.15 \mathrm{~K}$.

$\odot \mathrm{X}_{1} \mathrm{C}_{4} \mathrm{H}_{8} \mathrm{O}+\left(1-\mathrm{X}_{1}\right) \mathrm{CH}_{2} \mathrm{Cl}_{2}$

- $\mathrm{X}_{1} \mathrm{C}_{4} \mathrm{H}_{8} \mathrm{O}+\left(1-\mathrm{X}_{1}\right) \mathrm{CHCl}_{3}$

- $\mathrm{X}_{1} \mathrm{C}_{4} \mathrm{H}_{8} \mathrm{O}+\left(1-\mathrm{X}_{1}\right) \mathrm{C}_{2} \mathrm{H}_{4} \mathrm{Cl}_{2}$

a $\mathrm{X}_{1} \mathrm{C}_{4} \mathrm{H}_{8} \mathrm{O}+\left(1-\mathrm{X}_{1}\right) \mathrm{C}_{2} \mathrm{HCl}_{3}$

$\Delta \mathrm{X}_{1} \mathrm{C}_{4} \mathrm{H}_{8} \mathrm{O}+\left(1-\mathrm{X}_{1}\right) \mathrm{C}_{2} \mathrm{H}_{2} \mathrm{Cl}_{4}$

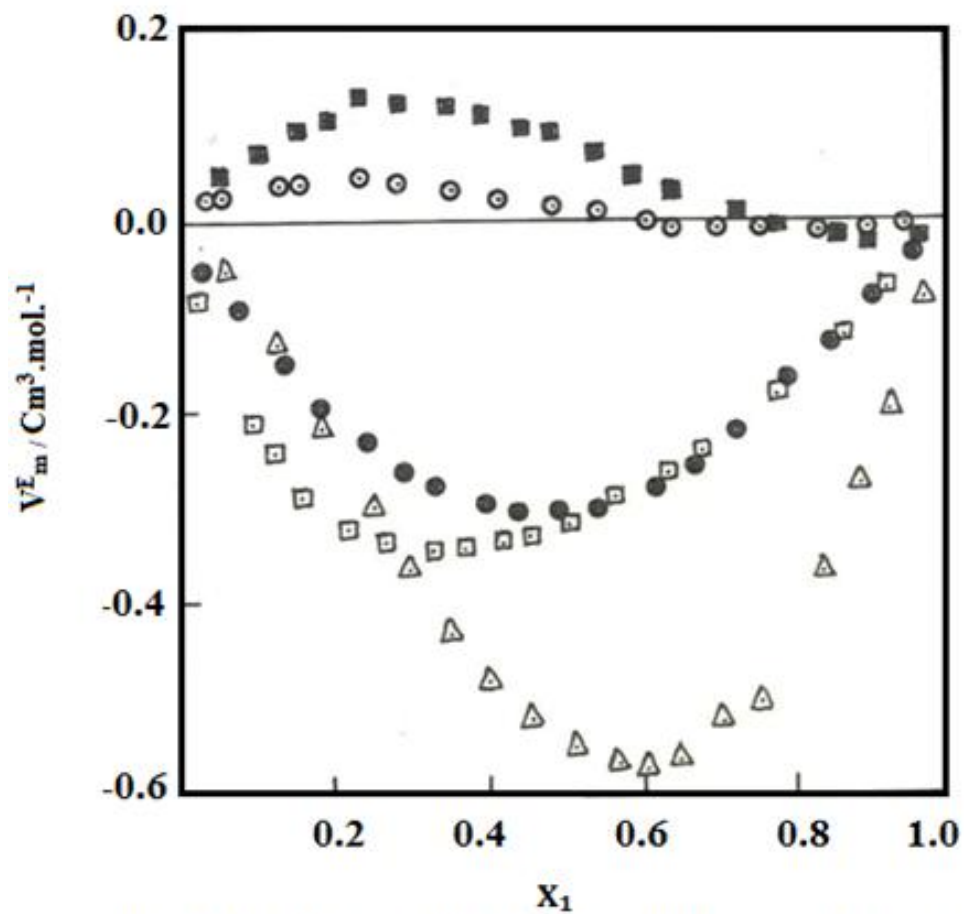

Fig. 2. Plot of Excess Molar Volume, $\mathrm{Vm}^{\mathrm{E}}$, against the mole

fraction of $\mathrm{C}_{4} \mathrm{H}_{8} \mathrm{O}, \mathrm{X}$, for the following systems at $\mathrm{T}=288.15 \mathrm{~K}$.

- $\mathrm{X}_{1} \mathrm{C}_{4} \mathrm{H}_{8} \mathrm{O}+\left(1-\mathrm{X}_{1}\right) \mathrm{CH}_{2} \mathrm{Cl}_{2}$

- $\mathrm{X}_{1} \mathrm{C}_{4} \mathrm{H}_{8} \mathrm{O}+\left(1-\mathrm{X}_{1}\right) \mathrm{CHCl}_{3}$

- $\mathrm{X}_{1} \mathrm{C}_{4} \mathrm{H}_{8} \mathrm{O}+\left(1-\mathrm{X}_{1}\right) \mathrm{C}_{2} \mathrm{H}_{4} \mathrm{Cl}_{2}$

a $\mathrm{X}_{1} \mathrm{C}_{4} \mathrm{H}_{8} \mathrm{O}+\left(1-\mathrm{X}_{1}\right) \mathrm{C}_{2} \mathrm{HCl}_{3}$

$\triangle \mathrm{X}_{1} \mathrm{C}_{4} \mathrm{H}_{8} \mathrm{O}+\left(1-\mathrm{X}_{1}\right) \mathrm{C}_{2} \mathrm{H}_{2} \mathrm{Cl}_{4}$

Volume 4 Issue 12, December 2015 


\section{References}

[1] Nath J. \& Rashmi, Fluid Phase Equilibria 58 (1989) 319.

[2] Nath J. \& Rashmi, J. Chem. Soc. Faraday Trans. 86 (1990) 3399

[3] Nath J. Chem. Soc. Faraday Trans. 87 (1991) 1345.

[4] Nath J. \& Panday J. G, J. Chem. Eng. Data 41 (1996) 844.

[5] Nath J.Chem. Thermodynamics 28(1996) 1083.

[6] Nath J. \& Panday J. G, J. Chem. Eng. Data 42(1997) 514.

[7] Nath J. Mishra S. K., Fluid Phase Equilibria 152 (1998) 277.

[8] Riddick J. A.\& Bunger W.B., Techniques of Chemistry , Vol.II, Organic Solvents: Physical Properties and Methods of Purification, $3^{\text {rd }}$ edn, A. Weissberger: editor. Wiley- Inter Science, New York, 1970.

[9] Timmermans, J. Physico-Chemical Constant of Pure Organic Compounds, Elsevier, Amsterdam, 1950.

[10] Redlich O. \& Kister A.T., J. Am. Chem. Soc. 71 (1949) 505.

[11] Mc.Glashan M. L. \& Rastogi R.P, Trans Faraday Soc .54(1958) 496.

[12] Mc.Glashan M. L., Chemical Thermodynamics Academic Press, London, 1979.

[13] 13.Srivastava R., Jain A. K., Nath J. \& Rashmi, Fluid Phase Equilibria, 58(1989) 319. 